\title{
Strategy for Digital Organization: Testing a Measurement Tool for Digital Transformation
}

\author{
Ljiljana Kontić \\ Faculty of Legal and Business Studies dr Lazar Vrkatić, Union University Novi Sad, Serbia \\ Đorđe Vidicki \\ Government of Vojvodina Novi Sad, Serbia
}

\begin{abstract}
Proactive leadership and investment are the key factors that determine a company's potential to become a digital organization. Based on the analysis of relevant literature, we will introduce a four-stage model. The companies are progressing through stalling, initiating, engaging and self-reinforcement stage. The main research question is: How to assess an organization's readiness for digital transformation? The main aim of this study is to propose the digital strategy based on four critical dimensions such as digital-first mindset, digital practices, empowered talent and data access and collaboration tools. The questionnaire comprised 32 questions to assess organization's position across aforementioned dimensions. Regarding different characteristics of national culture, the construct validity of research methodology developed in one society will be investigated for a Serbian sample. The sample consisted of 30 managers in one company. The research findings revealed possible practical implementation of an adapted questionnaire used by MIT Centre for Digital Business and Capgemini Consulting. The findings add to the existing literature on digital strategies in cross-cultural organizational contexts. The research findings revealed that an analyzed company redesigned organization as well as investment significantly in technology. The practical implementation and study limitation are suggested too.
\end{abstract}

Keywords

Digital organization, strategy, digital dexterity, transformation, organizational culture.

\section{Introduction}

In today's turbulent environment, innovation has become the mainstay of every organization. Innovation has become increasingly complex due to changing customer needs, extensive competitive pressure and rapid technological change (Kontic, 2008).

Regarding the implementation of technological changes, Serbia has fallen behind the Czech Republic and Hungary, but the competitive engineers in information technology (IT) sector represent the potential to improve technological implementation. For example, Belgrade gets intelligence containers. Mechanism through solar energy compresses garbage. When the container is full, the data is sent to mobile platform in operation centre and then they are organized to empty containers.

This paper contributes to the existing literature by empirical testing of a questionnaire used by MIT Centre for Digital Business and Capgemini Consulting (Capgemini Consulting, 2015) in a public organization from Serbia. Regarding different characteristics of national culture, the implementation of research methodology developed in a society will be investigated for a Serbian sample.

Organizations have to ensure that their corporate strategies are innovative to build and sustain competitive advantage (Kontic, 2008). The main purpose of research is to assess the organization's readiness for digital transformation and to propose innovation strategy for digital transformation. To 
achieve the goal, the following research questions have been formulated:

1. Which of digital business models can be implemented?

2. Which tool can be used to assess the organization's readiness for digital transformation?

3. Which is the successful strategy for digital organization?

Besides the introduction and conclusion, the paper is structured into three sections. The next section is devoted to theoretical background; the third one is devoted to the research methodology. The fourth section elaborates results and discussion.

\section{Theoretical background}

"Organizations have to make investment decisions much quicker and change their internal processes, with greater emphasis on decisions informed by data and analytics. Implementing digital business models is a complex endeavour, but there are a number of initiatives that can help incumbents revolutionize their own business model." (World Economic Forum, 2016, p. 12).

Being the first on the market it is no longer a guarantee for commercial success. The main question is how to innovate with lower costs, and how to retain talents. With cost-effective innovation it is not concern about additional funds; the management has to focus on product, service, marketing and competitiveness rather than financing (Kontic, 2002).

According to Schumpeter (1981), three main hypotheses about relationship between innovation and economy are the following:

1. Innovation, especially technological, gave capitalistic economy dynamic character though the process of "creative destruction". Due to main technological changes, new industries replaced the old ones.

2. Technological progress is one of the most important factors in explaining the increase of real national income per capita. Technological change gave an opportunity for increase of productivity and represents the main factor of the economic development.

3 . The possibility of taking temporary monopolist position stimulates stakeholders to develop technological innovation. Organizations gained short-term, but extreme high profits unless innovation succeeds. Pioneer gains temporary monopolistic position through increase of price or productivity, therefore it realizes entrepreneurship revenue. Imitators decrease prices. Innovation process effects economic and technological changes. It is opposite to perfect competitiveness. The innovation and unbalanced situations create the temporary monopoles.

The first step in digital transformation is developing the technological capabilities. To become profitable, an organization needs to have unused technological capabilities in order to exploit economies of scope through innovation (Kyläheiko, Jantunen, Puumalainen, Saarenketo, \& Tuppura, 2011).

It is necessary to identify and develop the most appropriate business model. The analysis of the best practice of a number of successful companies in digital transformation revealed five digital models (World Economic Forum, 2016, p. 19): customer-centric, extra-frugal, data-powered, sky net, and open and fluid. Moreover, in the next paragraph, the main characteristics of aforementioned models will be explained.

Customer-centric model focuses on transformation of front-office processes in organizations with decentralized structure. It can be applied in various industries.

In organizations with standardized structure extra-frugal model that provides a high-quality service at a low costs fits best (World Economic Forum, 2016, p. 19).

Data-powered model uses software intelligence. The main proposition to implement this model is an agile organizational culture focused on innovation.

Sky net model is based on artificial intelligence to increase productivity and flexibility of organization. Therefore, it can be used in the companies with engineer-led organizational culture.

Open and fluid model is characterized by constant dialog with the external world. The best known companies that used this model are Facebook and PayPal.

Based on relevant case studies, authors identified a process of digital transformation in selected industries that consist of three phases: pointing to existing products and/or services, decomposing existing business model and constructing new model (Remane, Hanelt, Nickerson, \& Kolbe, 2017, p. 41). 
Organizations usually fail to adapt new business models, besides the fact that their managers have not recognized new technological opportunities (Weill \& Woerner, 2015). Therefore, it is important to assess organizational readiness for digital transformation.

The environmental circumstances and organizational dynamic can be essential parts of framework for assessing readiness for digital transformation (Sanchez, 2017). Organizational success depends on industry structure. The main factors are: rivalry, threat of substitutes, bargaining power of customers, bargaining power of suppliers, and threat of new entrants (Porter, 1991). Resources and capabilities of organization can be the following: scale of operations, data talent, collaborative culture, cumulative learning, and innovation capacities (Sanchez, 2017).

Strategy, not only technology pushes organizations into digital transformation (Lanzolla \& Anderson, 2008).

Based on existing literature analysis and multiple case studies, authors identified four key factors of digital transformation strategies: use of technology, change in value creation, structural changes, and financial aspects (Matt, Hess, \& Benlian, 2015). The first factor can be described as managers' attitudes toward the new technology and the role of information technologies in organization. To exploit new technology usually means a change in value creation. Structural changes are mainly related to organizational structure and operations. Introducing new technology is an investment, therefore financial resources are included.

\subsection{How Organizations are Progressing to Become Digital?}

The journey towards becoming digital organization can be described through four key stages (Capgemini Consulting, 2015, p. 7):

1. Stalling - Characteristics of the organizations in this phase are inflexibility, and inability to deliver the results.

2. Initiating - The organizations start developing digital capabilities through investments in new knowledge and relationships.

3. Engaging - The organizations have various digital capabilities, and develop collaboration across the organization.

4. Self-Reinforcement - These organizations are very flexible, able to conduct quickly reorganization and/or self-organization.
Proactive leadership and investment are the key factors that determine a company's potential to become a digital organization. The four key factors are (Capgemini Consulting, 2015, p. 8): digital-first mindset, digitized practices, empowered talent, data access and collaboration tools (see Figure 1).

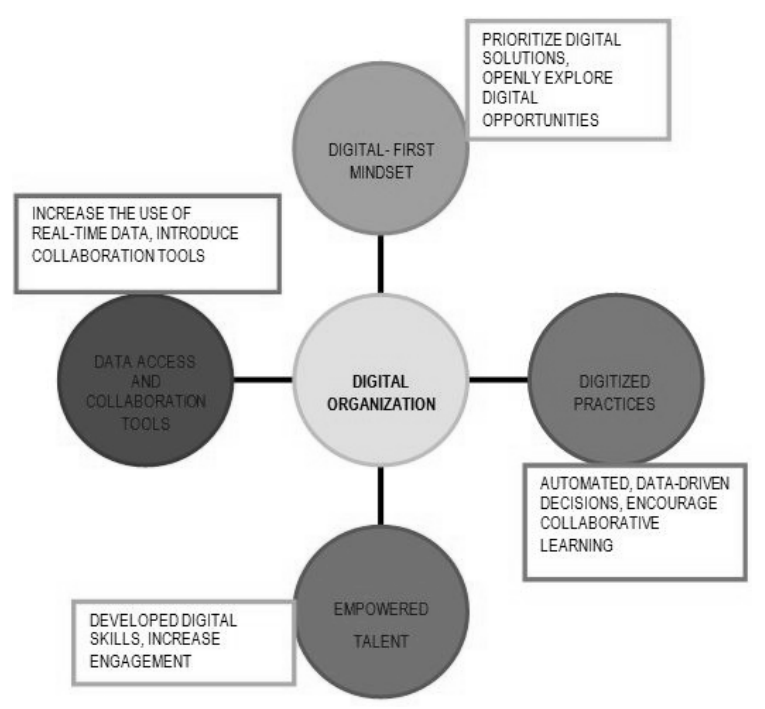

Figure 1 Key factors to become a digital organization Source: Capgemini Consulting, 2015, p.8

The first step in building a digital mindset is to explain benefits of the digital transformation to key stakeholders. The next stage for leader is to be a role model to employees, then to introduce monetary as well as non-monetary rewards to encourage digital change.

As it can be seen from Figure 1, empowered talent starts with developing digital skills. The first step is to define future skill requirements conducted by human resources and IT teams. Then they perform gap analysis between desired and current skills of the employees. The next step is to overcome the gap, followed by development of monitoring system. The necessary digital skills are analysis of meta data, use of social media, and mobile devices (Capgemini Consulting, 2015, p. 5).

One longitudal study included 400 large companies and revealed that most observed companies have used social media to implement various changes such as customer demands, internal processes and their business models (Capgemini Consulting \& MIT Sloan Management, 2017, p. 2). 


\section{Research methodology}

There are various tools that can be used in the assessment of the progress in digital transformation. In this study, the self-assessment tool developed by MIT Sloan Management and Capgemini Consulting (2015) has been used. The questionnaire comprises 32 questions to assess organization's stage in an aforementioned model. The questionnaire is translated into Serbian language and distributed to 30 managers in one public company. All of them filled the questionnaire due to survey insiders.

Respondents are asked to indicate their current views of internal factors in their organizations on the scale from 1 - disagree strongly to 5 - agree strongly. The original scale comprised a score between 1 and 6 for each item. However, the overall score legend has been modified. Therefore, the overall score legend is as follows:

- 10-20.5 STALLING STAGE

- 20.5-30.5 INITIATING STAGE

- 30.5-40.5 ENGAGING STAGE

- 40.5-50 SELF-REINFORCEMENT STAGE

We used manual presented by the authors of the original study (Capgemini Consulting, 2017, p. 14):

1. "Assign a score between 1 and 5 on each item

2. Calculate the score per factor by averaging the scores for items under that factor.

3. Sum the average scores calculated to arrive at the overall score for Organization

4. Compare the overall score with the overall score legend to understand organizations digital maturity

5. To identify which factor requires most improvement, undertake a relative comparison between the average scores per factor".

The research took place in March 2017 directly in Organization's facilities.

For the purpose of data analysis, descriptive statistics was computed. Data analysis was conducted using Microsoft Office Excel.

\section{Results and discussion}

The results of the study are presented in Table 1 .

Table 1 Summary of the research results

\begin{tabular}{|c|c|c|c|c|}
\hline 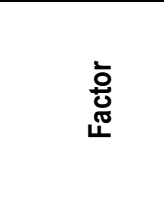 & $\underset{\Phi}{E}$ & $\begin{array}{l}0 \\
\stackrel{0}{0} \\
\stackrel{0}{0} \\
\stackrel{0}{0} \\
0\end{array}$ & 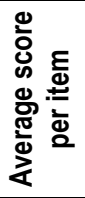 & 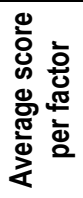 \\
\hline \multirow{2}{*}{$\begin{array}{l}\text { Digital-first } \\
\text { mindset }\end{array}$} & $\begin{array}{l}\text { We take } \\
\text { advantage of } \\
\text { digital solutions } \\
\text { whenever } \\
\text { possible }\end{array}$ & 97 & 3.23 & \multirow[b]{2}{*}{3.17} \\
\hline & $\begin{array}{l}\text { Employees } \\
\text { think of digital } \\
\text { technologies } \\
\text { when they } \\
\text { consider ways } \\
\text { to improve }\end{array}$ & 93 & 3.1 & \\
\hline \multirow{4}{*}{$\begin{array}{l}\text { Practices: } \\
\text { Digitized } \\
\text { Operations }\end{array}$} & $\begin{array}{l}\text { The core } \\
\text { operational } \\
\text { processes are } \\
\text { automated and } \\
\text { digitized } \\
\end{array}$ & 102 & 3.4 & \multirow{4}{*}{3.51} \\
\hline & $\begin{array}{l}\text { Employees } \\
\text { monitor } \\
\text { operations in } \\
\text { real time }\end{array}$ & 109 & 3.63 & \\
\hline & $\begin{array}{l}\text { Transactions } \\
\text { with suppliers } \\
\text { are digitized }\end{array}$ & 109 & 3.63 & \\
\hline & $\begin{array}{l}\text { Processes are } \\
\text { standardized }\end{array}$ & 101 & 3.37 & \\
\hline \multirow{3}{*}{$\begin{array}{l}\text { Practices: } \\
\text { Data-Driven } \\
\text { Decisions }\end{array}$} & $\begin{array}{l}\text { We make } \\
\text { decisions based } \\
\text { on data and } \\
\text { analytics }\end{array}$ & 102 & 3.4 & \multirow{3}{*}{3.42} \\
\hline & $\begin{array}{l}\text { We define clear } \\
\text { expectations } \\
\text { and metrics for } \\
\text { roles }\end{array}$ & 101 & 3.37 & \\
\hline & $\begin{array}{l}\text { We } \\
\text { systematically } \\
\text { gather and } \\
\text { analyze data } \\
\end{array}$ & 105 & 3.5 & \\
\hline \multirow{3}{*}{$\begin{array}{l}\text { Practices: } \\
\text { Collaborative } \\
\text { Learning }\end{array}$} & $\begin{array}{l}\text { Leaders } \\
\text { encourage } \\
\text { collaborative } \\
\text { problem solving }\end{array}$ & 75 & 2.5 & \multirow{3}{*}{2.81} \\
\hline & $\begin{array}{l}\text { Collaborating is } \\
\text { multidisciplinary } \\
\text { as well as } \\
\text { across speciali- } \\
\text { ties }\end{array}$ & 79 & 2.63 & \\
\hline & $\begin{array}{l}\text { The culture of } \\
\text { experimentation } \\
\text { and learning are } \\
\text { promoted in } \\
\text { organization }\end{array}$ & 88 & 2.93 & \\
\hline
\end{tabular}




\begin{tabular}{|c|c|c|c|c|}
\hline \multirow[t]{3}{*}{ 호 } & छ & 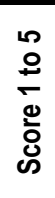 & 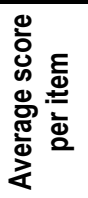 & 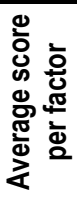 \\
\hline & $\begin{array}{l}\text { We have } \\
\text { centralized and } \\
\text { decentralized } \\
\text { decision-making } \\
\text { process }\end{array}$ & 86 & 2.87 & \\
\hline & $\begin{array}{l}\text { Our values are } \\
\text { transparent and } \\
\text { open }\end{array}$ & 93 & 3.1 & \\
\hline $\begin{array}{l}\text { Practices: } \\
\text { all items }\end{array}$ & & & & 3.25 \\
\hline \multirow{5}{*}{$\begin{array}{l}\text { Talent: } \\
\text { Technology } \\
\text { Experience }\end{array}$} & $\begin{array}{l}\text { Employees } \\
\text { have } \\
\text { experience with } \\
\text { mobile devices } \\
\text { and applications }\end{array}$ & 76 & 2.53 & \multirow{5}{*}{2.82} \\
\hline & $\begin{array}{l}\text { Employees } \\
\text { have } \\
\text { experience with } \\
\text { social media } \\
\text { tool and data }\end{array}$ & 88 & 2.93 & \\
\hline & $\begin{array}{l}\text { Employees } \\
\text { have } \\
\text { experience with } \\
\text { meta data }\end{array}$ & 70 & 2.33 & \\
\hline & $\begin{array}{l}\text { Employees } \\
\text { have } \\
\text { experience with } \\
\text { artificial } \\
\text { intelligence }\end{array}$ & 64 & 2.13 & \\
\hline & $\begin{array}{l}\text { Employees } \\
\text { have experi- } \\
\text { ence with the } \\
\text { internet }\end{array}$ & 125 & 4.17 & \\
\hline \multirow[b]{2}{*}{$\begin{array}{l}\text { Talent: Digital } \\
\text { skills }\end{array}$} & $\begin{array}{l}\text { Employees } \\
\text { have digital } \\
\text { skills }\end{array}$ & 108 & 3.6 & \multirow[b]{2}{*}{3.53} \\
\hline & $\begin{array}{l}\text { Employees } \\
\text { have the skills } \\
\text { necessary to } \\
\text { conduct digital } \\
\text { transformation }\end{array}$ & 104 & 3.47 & \\
\hline \multirow{3}{*}{$\begin{array}{l}\text { Talent: High } \\
\text { engagement }\end{array}$} & $\begin{array}{l}\text { Employees are } \\
\text { self-motivated }\end{array}$ & 89 & 2.97 & \multirow{3}{*}{3.3} \\
\hline & $\begin{array}{l}\text { Employees are } \\
\text { highly } \\
\text { competent }\end{array}$ & 109 & 3.63 & \\
\hline & $\begin{array}{l}\text { Employees } \\
\text { have } \\
\text { entrepreneurial } \\
\text { instincts }\end{array}$ & 99 & 3.3 & \\
\hline $\begin{array}{l}\text { Talent: } \\
\text { all items }\end{array}$ & & & & 3.27 \\
\hline $\begin{array}{l}\text { Data Access } \\
\text { and } \\
\text { Collaboration } \\
\text { tools }\end{array}$ & $\begin{array}{l}\text { Communication } \\
\text { and } \\
\text { collaboration } \\
\text { tools are } \\
\text { developed }\end{array}$ & 110 & 3.67 & 3.75 \\
\hline
\end{tabular}

\begin{tabular}{|c|c|c|c|c|}
\hline 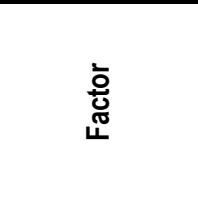 & $\stackrel{E}{\Phi}$ & 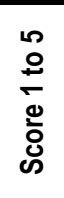 & 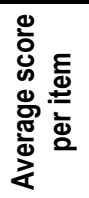 & 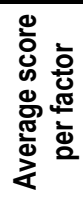 \\
\hline & $\begin{array}{l}\text { Employees } \\
\text { have access to } \\
\text { flexible } \\
\text { computing } \\
\text { power and } \\
\text { storage }\end{array}$ & 115 & 3.83 & \\
\hline \multirow{2}{*}{$\begin{array}{l}\text { Data Access } \\
\text { and Collabora- } \\
\text { tion tools: } \\
\text { Real-time cus- } \\
\text { tomer data }\end{array}$} & $\begin{array}{l}\text { Real-time } \\
\text { customer data }\end{array}$ & 113 & 3.77 & \multirow[b]{2}{*}{3.8} \\
\hline & $\begin{array}{l}\text { Integrated } \\
\text { end-user data }\end{array}$ & 115 & 3.83 & \\
\hline \multirow{4}{*}{$\begin{array}{l}\text { Data Access } \\
\text { and Collabora- } \\
\text { tion tools: } \\
\text { Integrated } \\
\text { operations data }\end{array}$} & $\begin{array}{l}\text { Integrated } \\
\text { financial data }\end{array}$ & 113 & 3.77 & \multirow{4}{*}{3.57} \\
\hline & $\begin{array}{l}\text { Integrated } \\
\text { operational } \\
\text { performance } \\
\text { data }\end{array}$ & 114 & 3.8 & \\
\hline & $\begin{array}{l}\text { Integrated } \\
\text { product/service } \\
\text { performance } \\
\text { data } \\
\end{array}$ & 101 & 3.37 & \\
\hline & $\begin{array}{l}\text { Integrated } \\
\text { supply-chain } \\
\text { performance } \\
\text { data }\end{array}$ & 100 & 3.33 & \\
\hline $\begin{array}{l}\text { Data Access } \\
\text { and Collabo- } \\
\text { ration tools: } \\
\text { all items }\end{array}$ & & & & 3.71 \\
\hline TOTAL & & - & 105.1 & 33.67 \\
\hline
\end{tabular}

Source: The authors' calculation

Based on the Self-assessment guide, the Organization is in the Engaging stage (33.67/50). The Organization has developed experience across digital-first mindset, practices, and talents. In this stage of development, Organization has used technology to standardize business operations.

The analysis of key factors showed that the average score per factor had data access and collaboration tools (i.e. 3.71), followed by talent (3.27), practices (3.25), and digital-first mindset (3.17). The potential areas to improve are:

1. Collaborative learning in the Organization (the lowest an average score per factor 2.81), and

2. Employees' technology experience (average score per factor was 2.82). 


\subsection{Strategic choice}

According to Soule, Puram, Westerman, \& Bonnet (2016), in engaging stage, the organization transformation is underway. Therefore, the organization's experience is growing. These characteristics determine digital strategy that is focused on operational efficiency in customer data and/or to improve collaborative tools.

Management of the Organization can implement data-powered operating model that is built around processes in analytics and software intelligence (World Economic Forum, 2016, p. 19). This model has been implemented in Google. Data-powered organizations have an agile organizational culture with the main goal to innovate through empirical experimentation. The success of this model is measured by return on investment.

To get organizations digital ready three activities are essential: upgrade, lead, and engaging (see Figure 2).

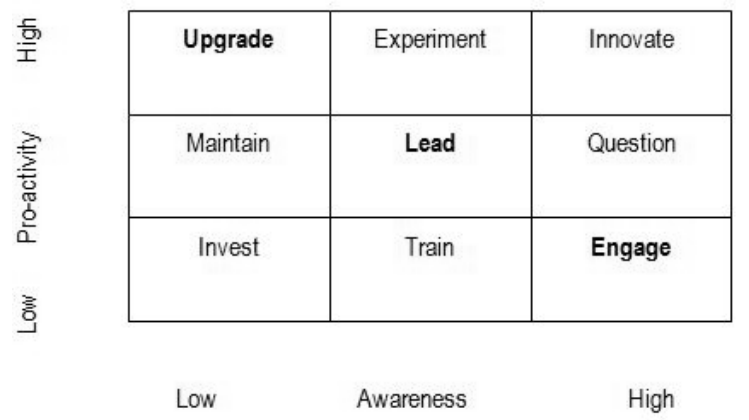

Figure 2 Pro-active leadership/Awareness Matrix Source: Waller, 2017, p. 10

\section{Conclusions}

This paper contributed to the existing literature by empirical testing a self-assessment questionnaire for digital transformation in a public organization from Serbia. Regarding different characteristics of national culture, the implementation of research methodology developed in a society has been investigated for a Serbian sample. The main purpose of research was to assess the organization's readiness for digital transformation and to propose innovation strategy for digital transformation.

The main question was how to innovate with lower costs and how to retain talents. In this study, we implemented a four-stage digital model: 1. Stalling, 2. Initiating, 3. Engaging, and 4. Selfreinforcement.

The key factors that determined the company's potential to become a digital organization have been proactive leadership and investment. Further, we investigated the four key factors such as digital-first mindset, digitized practices, empowered talent, data access and collaboration tools. The research instrument was self-assessment questionnaire to assess how organization is digitally mature. The research sample comprised of 30 managers in a public organization in Serbia.

The research finding revealed that the Organization is in Engaging stage. Therefore, an adequate strategic choice is digital strategy that is focused on operational efficiency in customer data and/or to improve collaborative tools. The optimal business model is data-powered model.

Limitation of this study is conducting research in one organization from transition environment. The future studies will include more organizations from various industries in Serbia, and then it will expand on other transition environments. SM

\section{References}

Capgemini Consulting and MIT Sloan Management. (2017). The Digital Advantage: How Digital Leaders Outperform their Peers in Every Industry. Retrieved March 5, 2017 from https://www.capgemini.com/wp-

content/uploads/2017/07/The_Digital_Advantage_How _Digital_Leaders_Outperform_their_Peers_in_Every_In dustry.pdf

Capgemini Consulting. (2015). Organizing for Digital: Why Digital Dexterity Matters. Retrieved January 10, 2017 from https://www.capgemini.com/consulting/wpcontent/uploads/sites/30/2017/07/digital_orgns_cover_0 8-12.pdf

Capgemini Consulting. (2017). The Digital Talent Gap Developing Skills for Today's Digital Organizations. Retrieved January 5, 2017 from 2013: https://www.capgemini.com/wpcontent/uploads/2017/07/the_digital_talent_gap2709_0.pdf

Kontic, L. (2008). Innovation - challanges for future. Belgrade: Zaduzbina Andrejevic.

Kontic, L. (2002). Innovation - condition for survival. Belgrade: Zaduzbina Andrejevic.

Kyläheiko, K. J., Jantunen, A. , Puumalainen, K., Saarenketo, S., \& Tuppura, A. (2011). Innovation and internationalization as growth strategies: The role of technological capabilities and appropriability. International Business Review, 20 (5), 508-520.

Lanzolla, G., \& Anderson, J. (2008). Digital transformation. London Business School Review, 19 (2), 72-76.

Matt, C., Hess, T., \& Benlian, A. (2015). Digital transformation strategies. Business and Information Systems Engineering, 57 (5), 339-343.

Porter, M. (1991). Towards a Dynamic Theory of Strategy. Strategic Management Journal, 12, 95-117.

Remane, G., Hanelt, A., Nickerson, R. C., \& Kolbe, L. (2017). Discovering digital business models in traditional industries. Journal of Business Strategy , 38 (2), 41-51. 
Sanchez, M. A. (2017). A framework to assess organizational readiness for digital transformation. Dimension Empresarial, 15 (2), 27-40.

Schumpeter, J. (1981). Capitalism, Socialism and Democracy. Zagreb: Globus.

Soule, D. P., Puram, A., Westerman, G. F., \& Bonnet, D. (2016). Becoming a Digital Organization: The Journey to Digital Dexterity. Retrieved January 10, 2017 from SSrn: http://ssrn.com/abstract=2697688

Waller, S. (2014). Be digital Ready. Retrieved January 10, 2017 from Simon Waller:

https://simonwaller.com.au/wp-

content/uploads/2014/12/Digital-Ready-white-paper.pdf

$\bowtie$ Correspondence

\section{Ljiljana Kontić}

Faculty of Legal and Business Studies dr Lazar Vrkatić Bulevar oslobođenja 76, 21000, Novi Sad, Serbia

E-mail: ljiljana.kontic@yahoo.com
Weill, P., \& Woerner, S. (2015). Thriving in an increasingly digital ecosystem. MIT Sloan Review, 56 (4), 27-34.

World Economic Forum. (2016). Digital Transformation of Industries: In Collaboration with Accenture. Retrieved January 10, 2017 from World Economic Forum: http://reports. weforum.org/digital-transformation/wpcontent/blogs.dir/94/mp/files/pages/files/digitalenterprise-narrative-final-january-2016.pdf 